\title{
Preservation education in South African library and archive degree programmes
}

\author{
Kate Murray' \\ Emory University Libraries, \\ Preservation Office, Atlanta, Georgia USA 30322-2870 \\ kate.murray@emory.edu
}

Received 20
Accepted $23^{\text {th }}$ May 2003
February 2006

This paper investigates preservation education options for library and archive students at degree granting institutions in South Africa through examining the following questions: which institutions offer separate classes or modules dedicated preservation issues; what academic levels are the existing classes directed towards and how often are they offered; what preservation issues are covered in existing classes and modules; what is the preservation-related experience of the instructors, and; how do South Africa's offerings compare internationally? The paper also evaluates the appropriateress of the preservation content offered against established benchmarks.

Key Words: Preservation Education; Library; Archives; South Africa

\section{Historical context for preservation education}

Concern for the preservation of library material has a long history as Cloonan concisely outlines in her 1994 book, Global Perspectives on Preservation Education. The first preservation professionals were medieval scribes who repaired the animal skin or cotton rag manuscripts they created. The maintenance of existing items, however, was not as high a priority as fashioning new ones. Generally, the time-honoured apprenticeship system focused on the creation of books and paper objects but not necessarily the repair of these items. Cloonan (1994: 7) summarises that the history of preservation education is a developmental process that "gradually evolved from a hands-on apprenticeship served under a master bookbinder to a management-oriented discipline where a Master's degree in librarianship and sometimes also an advanced certificate comprise the training." Systematic preservation education for the vast majority of information workers, however, is not established in many parts of the world.

Formal preservation education as part of library and information science (LIS) degree programmes is a fairly recent advancement. One often-credited impetus for their establishment is the famous flood of 1966 in which the River Arno spilled over its banks and flowed into the vulnerable libraries of Florence, Italy (Ogden 1979). This disaster forced a rethinking of preservation responsibility and fostered a new spirit of co-operation between bookbinders and librarians. The response to the problems caused by the flood led to new techniques and ideas about bookbinding, book repair, materials, storage as well as, among other things, the establishment of the Preservation Office at the US Library of Congress. More important from the global perspective, however, the destructive flood brought "librarianship back to a traditional responsibility" of preservation (Ratcliffe 1986: 493).

Not least among the lessons to be learned from Florence was the lack of information among librariaris on the scientific knowledge and expertise which already existed. There was little awareness of it and, when revealed, no ready means of applying it. [The flood] brought into focus the absence of instruction in the use and management of existing technology for librarians and binders alike in this country [the UK]. It also showed ignorance among scientists and technologists of library needs and interests (Ratcliffe 1985: 87).

Librarians and archivists realised they had neglected the long term physical well-being of their collections.

\section{Preservation in global professional LIS education}

Until fairly recently, most information workers worldwide would complete their professional education without knowing a thing about preservation, either by choice or circumstance. As preservation problems became part of everyday working life in ageing and evolving format collections, it became clear that preservation should be considered an essential - rather than a peripheral - aspect of professional LIS education.

Thebridge and Matthews (2000: 68) insist "the basic education of information workers needs to have at its heart a preservation ethos." Their 200 I survey of preservation management training in the UK determined "the need was expressed for preservation to become part of the core curriculum of information studies courses ... [The] incorporation

1. Kate Murray is Audio and Visual Media Collections Conservator, Emory University Libraries, Atlanta,Georgia, USA. She graduated with an MILS at UCT, South Africa, in 2002. 
of preservation as a core study would ensure that library managers of the future recognise preservation as a key rather than a fringe part of the management of all types of library and information services" (Matthews and Thebridge 2001: 445-446). These researchers advocate a fundamental shift in professional education for LIS workers in which professional education programmes recognise preservation as a central, intrinsic part of librarianship and archival studies and, as such, consider it an essential overarching component of the professional education process - something that is not the norm worldwide. Although many library schools "offer at least one course in preservation, it is not usually integrated into the core courses, nor is it necessarily a required course" (Cloonan 1997: 182). In addition, many courses are taught often by less experienced and less established faculty.

Barnes (1987: 38-39) points out that "an essential ingredient in the training of librarians should be the promotion of awareness of conservation needs, practices, and resources and their management and application in libraries." Meadows (1987: 20) agrees that all information students need a background in preservation and conservation.

All students need to think of the limitations imposed on communication by the physical properties of the medium, and also of the relative importance of conservation and preservation. Thus even totally computeroriented information scientists would do well to ponder these points in relation to (say) magnetic tape.

He goes on to suggest the nature and extent of preservation instruction be based on a "need-to-know" principle, where education and training can "be aimed at the immediate needs of the students [and] those who subsequently require additional knowledge can be trained on the job" or through additional specialised education (Meadows 1987: 20).

The first preservation courses for information professionals emerged in the late 1960s and early 1970s in the US and UK. Other regions followed suit to varying degrees. In order to view the South African preservation education perspective in a global perspective, this paper will summarize briefly the situation in other important regions.

\section{United States}

While a number of training programmes in art conservation have been available in the US since the early 1960s, the first degree-granting programme specifically addressing the preservation needs of libraries and archives began in 1980 at The School of Library Service (SLS) at Columbia University in New York and offered two master's degree programmes, one for preservation administrators and one for hands-on conservators. When SLS closed in 1992, the programme reorganized and moved to the University of Texas at Austin School of Information where it resides today although it has evolved over the years. This programme remains the only option in the US for those who want to specialise in the preservation administration or conservation of library and archives materials at the postgraduate level. Other universities have specialisation tracts for those who want to focus on preservation as part of their overall Master's of Library Science (MLS) degree programme. Still others offer continuing education programmes outside of MLS degree programmes. According to the Society for American Archivists (SAA), all Master's of Archival Studies (MAS) programmes "must include coursework ... in complementary areas such as conservation" (Society of American Archivists 2002).

For a while, the trend in the US looked like library education itself was on the decline and so was preservation education. The field experienced a resurgence of sorts as demonstrated by 1995 statistics from the ALA's Preservation Education Directory edited by Coleman.

Several schools have added preservation courses to their syllabuses, and other schools have increased the number of preservation courses they offer. This edition of the Directory lists 78 courses; the previous edition [1990] listed 52 courses. Other courses that include a preservation component have also grown in number: 134 in this edition as against 124 in the last. The number of schools offering continuing education programs that include preservation has risen from 14 in the $6^{\text {th }}$ edition to 20 in this one. The value of practical experience for students is likewise recognised by an increase in the number of internships listed: 7 in the earlier edition; 18 in the new one (Coleman 1995).

This directory was updated in 2002 by Wiseman and Arnot and shows even more preservation courses available across the country.

\section{United Kingdom}

One defining event for preservation education in the UK was the publication of Preservation Policies and Conservation in the British Libraries: Report of the Cambridge University Library Conservation Report (Ratcliffe and Patterson 1985), better known as the Ratcliffe Report. In a nutshell, this report laments the lack of preservation courses in library schools and the lack of preservation information available to library staff.

This influential publication had two major results. First, it led to the establishment of the National Preservation Office (NPO) in 1984 which, very briefly summarised, is jointly funded by a number of institutions including the British Library and its role is "to provide an independent focus for ensuring the preservation and continued accessibility of library and archive material held in the United Kingdom and Ireland" (National Preservation Office 200I). The second major result 
was the 1986 Library Association (LA) organised seminar Education for Preservation where, among other things, experts decided that conservation training is a speciality outside of library school domain but preservation education is not (Clements 1986: 136).

More recently, Feather informally surveyed BAILER (British Association for Information and Library Eclucation and Research) LIS academic departments and found the community has learned, to varying degrees, from the Ratcliffe Report.

All the respondents are teaching some aspect of preservation management in some part of their respective programmes; three offer a full module in the subject, although in at least one other institution preservation and conservation forms a very substantial part of a core postgraduate module. All three full modules are optional, and the wording of the response from one institution suggests that in some years their module is cancelled for lack of student interest (Feather 2000: 19-20).

He goes on to explain that, instead of being relegated to specialised historical bibliography or rare books classes, preservation is now being incorporated into core curriculum classes, implying that "preservation management is apparently recognised as an essential part of a librarian's professional toolkit" (Feather 2000: 20).

Australia

Library and archive preservation in Australia "as a special field of study, has only recently been acknowledged ... and programmes for teaching library preservation to conservators and librarians are in the early developmental stages" (Lyall 1991: 64). The Australian experience somewhat parallels that of South Africa in that the acceptance of and commitment to the importance of preservation came late to both countries and few of the LIS and archive degree programmes offer preservation education. Lyall (1991: 66) reports in the late 1980s only two library schools teach preservation courses although "it is hoped within a short period of time, many Australian library schools will be offering training courses in preservation."

Africa

Outside of South Africa, consistent preservation education in Africa is limited. A 1999 JICPA (Joint IFLA-ICA Committee for Preservation in Africa) sponsored survey of preservation resources in Africa (compiled by Coates and published in 2001) summarises the situation.

It would appear that no formal training in conservation is offered in Africa, although numerous short courses are provided or are merely introductory modules offered as part of archival or introductory training. Indigenous training consists for the most part of apprenticeships and on-the-job training ... The few most highly trained conservators in Africa are to be found in English-speaking countries (Coates 200 I: 4-5).

"It is a matter of concern, even dismay, that expertise and facilities are so extremely limited" in a continent as large as Africa, Coates (2001:6) goes on to say. He does demonstrate hope for the future in saying "expertise and facilities do at least exist and this could be regarded as a foundation on which to build." (Coates 2001: 6).

Countries like Botswana, Zimbabwe, Gabon, Kenya, Namibia, and Uganda have all demonstrated their commitment to, or at least interest in, the importance of preservation education in various professional publications (Kukubo 1995; Mazikana 1995; Rosenberg 1995; Sonnet-Azize 1995; Mnjama 1996; Rhys-Lewis 2000; Coates 2001). Mnjama's recent study of archival institutions in the East and Southern Africa Regional Branch of the International Council on Archives (ESARBICA) member countries addresses the inadequacies of archival education in the region. He comments that Kenya, Botswana, Zanzibar, Tanzania, Zambia as well as South Africa "have made considerable progress towards managing their archival heritage" compared to other member states (Mnjama 2005: 459). Preservation activities and the training of preservation staff, however, continue to lag behind.

One of the areas where archival under-development can easily be noticed in many of the archival institutions surveyed related to the provision of archival conservation and restoration facilities. The development of preservation and conservation facilities has been hampered by lack of facilities as well as lack of trained staff (Mnjama 2005: 463).

Preservation education is scarce in the lesser developed African countries for a variety of reasons. Alegbeleye (1991:6970) summarises some of the possible causes for this paucity, including the dearth of teachers at both the professional and paraprofessional levels, limited economic conditions, fluctuating currency values which restrict the importation of raw materials and the exportation of staff for training, and unstable political environments.

Yet despite all the roadblocks to widespread and successful implementation, preservation is an important concern throughout Africa.

Preservation and conservation [is] a valid issue in developing countries ... We have read papers about preservation and conservation, but do we really know the needs in tropical countries as far as preservation and conservation are concerned? The answer is no. This is because no systematic research has been undertaken to 
reveal what the actual problems are, and what measures should be taken in meeting those needs (Wambugo 1991: 76).

Wambugo places the responsibility for increasing education and training options squarely on the shoulders of more developed countries and international organisation such as IFLA (The International Federation of Library Associations and Institutions) and UNESCO (United Nations Educational, Scientific and Cultural Organization). As Dyab (2002) mentions, UNESCO especially was instrumental in supporting the establishment of library schools in several countries including Uganda and Kenya. These organisations have made some important inroads towards realising this goal but such initiatives must stress capacity building and self-reliance to be successful in the long term (Mazikana 1995: 27; Rhys-Lewis 2000: 21). Coates (2001: 7) also stresses that any education or training initiatives in Africa must be carried out "on the ground" by local/national preservation committees for the best chance of success.

\section{Preservation education in South Africa}

South African experts recognise that preservation awareness and action came late to the country compared to the UK and the US. Westra (1986: 141) says "libraries and archives [in South Africa] have given far less attention to preservation than their colleagues abroad." Maree (198I: I) describes the burgeoning preservation field in the South Africa twenty five years ago as "unorganised but exciting." He goes on to say that "we have to admit that we have not only lost precious time but also irreplaceable items of our collections. We will have to work very hard to rectify the situation but also to see to the problem of training restorers for our own future needs" (Maree 1981: I). Weiner (1986: 7) adds "there is a great need for, and interest in, basic conservation training."

In the late 1980s, Westra comments on the uneven training of South Africans working in the preservation field.

At the moment [in 1986] about a dozen qualified paper restorers are working in South African institutions and a further three or four are working privately. Most of them have received their education and training in Great Britain or Germany. Looking at their formal qualifications one is struck by the great variety of diplomas and the apparent lack of standardisation in their education. It is of course a relatively new field, but it seems to me that qualified restorers can have anything from a doctorate in chemistry plus specific training in paper restoration, to matric or even lower basic schooling plus special courses (Westra 1987: 36-37).

Twentyman Jones (1987: 118) asserts that "in South Africa we have not reached the stage of employing preservation officers, and we are only just realising the need to employ restorers or conservators." She discusses an un-referenced survey of all the syllabi of librarianship courses at South African universities, the results of which indicated that "no specific courses are offered on conservation" and very few included any aspects of preservation "such as storage, care and repair or book production, and book binding" (Twentyman Jones 1987: 121). She concludes "it is thus clear that schools of librarianship need to re-examine the courses on offer and incorporate this important aspect of librarianship into their syllabuses" (Twentyman Jones 1987: 121).

More recently, Ngulube agrees that African archival preservation education is underdeveloped.

In the case of South Africa, training facilities for archivists in general, and conservationists in particular, are inadequate. One can only hope that some archivists have received training from abroad and that once they have acquired the skills they impart them to all concerned though some in-house training programme (Ngulube 2003: 169).

A growing concern is the lack of understanding of the specific problems of preserving of digital resources.

There is little appreciation of the preservation challenges of digital media ... In sub-Saharan Africa, the volume of digital information media produced is comparatively small, but the preservation challenges are particularly acute. If digital media cannot be preserved, part of Africa's heritage is being lost (Lor 2005: 63).

While it is clear that the interest in preservation is strong, these experts agree that the local training needed to address the needs of library and archive collections is not up to par.

\section{Essential topics for preservation education}

South African experts have acknowledged for a long time that the country needs to play catch-up in both establishing preservation programmes in institutional repositories and educating information professionals about preservation issues. Preservation experts agree, however, that not all LIS students need the same extent of coverage of the preservation issues during their professional education. They should have a basic understanding of the underlying topics upon degree conferment but also know when and where to seek additional instruction.

This study seeks to determine if South African LIS programmes cover the basic topics to which, experts determined, all LIS students should be exposed (Banks 1979; Feather 1986; Barnes 1987; Meadows 1987; Russell 1991). These baseline topics include basic book repair, environmental control and monitoring, disaster preparedness and recovery, 
binding options, staff and user education, traditional reformatting (including microforms and photocopying), and digitisation.

\section{Survey of available 2002 preservation courses}

As part of a Master's thesis project, a survey conducted in spring 2002 sought to determine to what extent South African LIS and archive academic degree programmes address preservation issues in their curricula (Murray 2002). The survey was designed to determine the strength of commitment to preservation education, demonstrated by having a dedicated preservation course or a preservation component as part of a wider scope course. If such courses did exist, the survey sought to discover the content of the course and the qualifications of the instructor with regards to preservation. It was equally important to establish where courses did exist and where they did not exist.

The survey was distributed to 17 South African institutions offering degrees in librarianship or archival studies. The identities of these institutions and departments were confirmed through several sources. The primary foundation was a catalogue resulting from a separate research project that compiled contact information for all LIS programmes in Africa in 2001. The baseline group for this Africa-wide study was culled from established published reference tools including Guide to Higher Education in Africa (Langlois 1999) and Directory of African Universities (Mboungou-Mayengué 1988). References specific to South Africa also included the Directory of Library and Information Schools in SADC Region (Southern African Development Community [SADC] Secretariat Library 1998) and Directory of Educational Programmes (Youth-In-Finance Counselling Services 1999). The identity of the school, department, degree programme, and department head was confirmed through additional verification via the Internet. Some schools and/or departments were identified as offering LIS education but corresponding websites, when available, were either very out of date or ambiguous about the exact nature of the degrees offered. For example, one institution was listed in a published source as offering a degree in information science but, after examining the courses list on the Internet, the institution was not included in the study because the focus of the degree was on computer science rather than library science. In other instances, it was impossible to confirm via the Internet or other sources if the degree programme listed was, first, still offered and, second, appropriate for this study. These listings were included in the study survey pool so as not to exclude them without further investigation. In addition, Internet searching was conducted to determine if any programmes not listed in published sources existed. The South African subset of this extensive Africa-wide contact list was current at the time of this study in 2002.

From the survey pool of 17 institutions, II responded with usable data. Four institutions no longer offer traditional LIS degree programmes and two institutions did not respond to the survey.

\section{Overview of preservation education offerings}

The survey determined that out of the $\mid$ I responding institutions offering LIS and archive education in South Africa, two have a separate class dedicated to preservation issues, another six institutions cover some preservation issues as a unit or module (hereafter referred to as a module) in a core curriculum class, and three institutions do not cover preservation issues at all in their curriculum.

\section{Instructors}

The first dedicated preservation class, taught by an established preservation expert, has been offered annually as an elective course for some time and its syllabus is widely distributed. The second, a new core curriculum class dedicated to preservation issues, was in the early planning stages at the time of the survey and was scheduled to be offered annually starting in July 2002. The proposed instructor was not determined but was thought to be an adjunct faculty member. The syllabus was unavailable at the time of the survey. [NB. Recent attempts in late 2005 to get more information on this course yielded no further results; it is unclear if this course was offered to students. Moreover, the Archives and Records Management degree, of which this class would have been a part, may no longer be offered by this institution.]

The instructors for the preservation modules are the same faculty members who teach the rest of the course. Five are full time permanent faculty and one is a guest lecturer. None are preservation specialists.

\section{Academic Level}

When taught as a module or unit, preservation is addressed primarily in introductory librarianship courses, such as Library Administration, Library and Information Practice, Collection Development and Management and Information Services Management. At two distance learning institutions, the names of the relevant modules clearly incorporate the words preservation or conservation.

Most of the available education options, both dedicated classes and modules, are offered at the undergraduate and postgraduate diploma or fourth-year level. At one institution, modules are available at the Honours level. There are no 
options for the Master's level. The dedicated classes run annually as do most of the modules. Two institutions run the modules every term.

Continuing Education Options

Neither of the two institutions with dedicated preservation classes offer continuing professional education options for working professionals, nor do most of the institutions with a preservation module. One distance learning institution makes its modules available to working professionals. Another institution which does not offer a preservation class or module, offers an occasional summer school course for non-preservation professionals.

\section{Preservation course/module content}

Almost three-quarters (73\%) of the LIS and archive training institutions in South Africa include at least some aspects of preservation in their curricula.

This section explores the content of the available education options and analyzes the appropriateness of the content against benchmarks set by LIS education and preservation experts.

\section{Basic Book Repair}

One of the most widely taught aspects of preservation is 'basic book repair,' included in $64 \%$ of all the available options. While this is an encouraging statistic, it can be ambiguous as well because, as Pederson (1987: 214) says, "a little knowledge is a dangerous thing" when it comes to hands-on repair. Sometimes an enthusiastic novice can cause more damage than what originally needed repair.

Since only one of the instructors is an established preservation expert, how do the other instructors define 'basic book repair'? What types of repairs are the students advised to perform on their own? What materials are used? Are the materials' condition, age, and value considerations covered? Are the limitations of the instructor's book repair/ conservation knowledge clearly understood by both the students and instructor? Are the students advised when to consult a trained conservator and how to find one?

Experts such as Feather (1986: 499) and Russell (1991: 82-83) feel strongly that hands-on physical repair should be deemphasised in overview modules and even in dedicated classes for non-conservators. This may not be practical in South Africa, however, where there are so few trained conservators to go around and information professionals may need to undertake some remedial repairs on their own. As Cameron (1985: 177) notes, some collections "have to wait for a considerable time" before they receive "proper attention" due to the lack of available staff and facilities in the country.

Basic book repair instruction is a worthwhile skill to learn for information generalists as long as anything beyond remedial treatment is left for the highly trained experts.

Environmental monitoring and control

Only a little more than half $(55 \%)$ of the classes/modules covered environmental monitoring and control, a topic considered essential for even overview preservation modules courses (Feather 1986: 499). It is an established fact that monitoring and controlling the library and archive environment can greatly increase the life span of the materials (Patkus 1999). The challenges of environmental monitoring and control in South Africa, with its diverse and sometimes extreme climate as well as limited financial resources, is acknowledged by a number of respected in-country experts (Weiner 1987; Maree 1988; Harris 1993; Peters 1996a; Peters 1996b). Information workers need to understand the fundamentals of the key issues and the impacts they can have on collections. At the minimum, LIS professionals need to be aware of the dangers of wide temperature or $\mathrm{RH}$ (relative humidity) fluctuations and how to deal with them at a rudimentary level to reduce preventable damage.

Disaster planning and recovery

Only $36 \%$ of the available options cover disaster planning and recovery, one of the core topics of preservation. A basic knowledge of what to do and whom to call in the case of an emergency is important for all information workers professional and paraprofessional alike.

It is unfortunate that institutional staff often learn about the advantages of emergency preparedness through hard experience, but an emergency does not have to become a full-fledged disaster. ... An increasing number of professionals know that small-scale emergencies can be contained if staff members are prepared to react quickly (Patkus and Motylewski 1999).

All library and archive professionals should be aware of this concept as an integral part of their responsibility for the health and well-being of their collections.

Binding options

"Criteria and decision making for binding" should be included in all levels of preservation education according to Feather (1986: 499) yet only $36 \%$ of the current education options cover library binding options in their curricula. Almost every 
library and archive has items bound or rebound at some point. Some institutions, like the University of Cape Town (UCT), have a private library bindery on campus while others use commercial binders. Irrespective of who performs the binding work, library and archive staff need to know what binding options are available, what are the criteria for deciding which styles of binding are appropriate for different types of material, and how to establish benchmarks for quality control.

\section{Staff and user education}

It is disappointing to learn that only approximately one-third (36\%) of the available training options cover staff and user preservation education. De Stefano (2000: 8) stresses all staff "must be trained with confidence to contribute to the preservation and/or conservation of the repository's materials; otherwise, they will be in effect, working counterproductively against the efforts of a program."

Traditional reformatting: microforms and photocopies

With increased interest in and funding for digital projects, traditional reformatting options like microfilm, microfiche, and preservation photocopying may begin to fall out of favour. They may not be as cutting edge as digitisation but they are still very viable options with proven track records for long term preservation (Dalton 1999). Yet, only three education options (27\%) covered this vital topic. One reason may be that there are few original institutional preservation microfilming projects currently underway in South Africa outside of the National Library of South Africa (NLSA). Most institutions instead purchase the user copies of titles from local and international commercial vendors. Even if individual institutions are not currently involved in the filming aspect, most have shelves of film and fiche in their collections and they continue to purchase new film to augment, replace, or sometimes in lieu of paper-based collections. In addition, information professionals need to be able to recognise and negotiate acceptable quality levels from commercial vendors. There are many established standards and guidelines for reformatting including the American Library Association's (ALA) Guidelines for Preservation Photocopying of Replacement Pages (1990), the National Library of Australia's Policy on Preservation Copying of Collection Materials (2002) and any number of appropriate ANSI/NISO (American National Standard Institute/National Information Standards Organisation) or ISO (International Organisation for Standardisation) standards that can act as valuable guidelines for South African decision-makers.

New reformatting technologies: digitisation

South Africa had been somewhat slow to embrace the digital revolution but it is now firmly established. Lor (2005: 64) comments that most African digitisation projects are "insignificant in comparison with similar projects in the developed world, [yet they] are not too small to raise issues of acquisition, bibliographic control, organisation, access and long-term preservation." Successful South African projects include DISA (Digital Imaging South Africa), the University of the Western Cape Robben Island Mayibuye Archives' Builders of the Nation Poster Exhibit, and the University of Cape Town's Manuscripts and Archives The San (Bushman) Photographs of Dorothea Bleek. Unfortunately, only very few of South African LIS training programmes (18\%) were giving curriculum time to this increasingly important resource at the time of the survey. Lor (2005: 65) points out that "we do not currently know how significant Africa's production of digital material is in conjunction with that of conventionally printed material" and "this is all the more reason to be concerned about it disappearance."

In her 2001 paper, Digital Libraries: Preserving Information Resources for Contemporary South African Scholarship, Peters emphasises the growing need trained professionals in the areas of digital technology and preservation specifically in South Africa.

There is an ongoing need to work together as a community to establish measures to build capacity and increase expertise with issues of digital technology in higher education. A strong voice is needed to express the need for high quality education and information access to all people. A collaborative effort will most efficiently drive the development of needed products, to grow a demand for commercial services and to build technically sustainable solutions that support international standards to meet the needs of digital preservation that will effectively secure long-term access to digital information resources (Peters 2001).

There can be no doubt that this emerging discipline will continue to expand its influence within libraries and archives and those who work in them will need to be prepared for this widening reality. A basic understanding of all aspects of digitisation including selection criteria, image quality, metadata encoding, and rights management is a must for future professionals.

\section{Conclusions}

With a variety of available options, preservation education in South Africa has made some significant strides in recent years. The benchmark of success, however, should be the quality rather than the quantity of the offerings. In this regard, 
South Africa is still behind the curve internationally since relevant and high quality preservation education is not yet an established component of LIS degree programmes. It is true that eight out of II institutions indicate they include preservation as part of their curricula but few really give it full consideration or cover the essential issues. At least two institutions with preservation modules admit that the module occupies only a "small part" of syllabus' time. Moreover, for the most part, the collective syllabi - especially for the modules - do not accurately reflect the practical needs of working LIS professionals as determined by field experts. In addition, the content of the educational offerings needs to be updated for today's evolving collections. Libraries and archives preservation challenges are rapidly expanding beyond the world of book and paper to encompass a wide variety of formats - including audiovisual material and items born digital - and LIS graduates will be expected to safeguard this material for future generations. While South Africa is certainly not alone on the world stage in this respect, South African LIS and archive degree programmes need to re-evaluate their tenuous commitment to preservation education in their curricula to empower future graduates with all the skills essential for success.

\section{References}

Alegbeleye, B. 1991. The problems of teaching conservation and preservation in developing countries: Nigeria. A case study within Africa. In Education and training for preservation and conservation: Papers of an international seminar on 'The teaching of preservation management for librarians, archivists and information scientists,' sponsored for IFLA, FID, and ICA, Vienna, April II13, 1986. IFLA Publications 54. edited by J.R. Fang and A. Russell. Munich: K.G. Saur. 67-72.

American Library Association. 1990. Guidelines for preservation photocopying of replacement pages. Association for Library Collections and Technical Services. [Online]. Available: http://www.ala.org/ala/alctscontent/alctspubsbucket/webpublications/ alctspreservation/guidelinesforpre/guidelinespreservation.htm [18 December 2005].

Banks, P.N. 1979. Education for conservators. Library journal. May 1:1014-1017.

Barnes, M. 1987. In-house conservation education. In Conservation in crisis. Proceeding of a seminar at Loughborough University of Technology 16-17 July 1987. National Preservation Office seminar papers I. London: National Preservation Office, British Library. 35-43.

Cameron, E. 1985. Conservation and restoration of manuscript material. In Proceedings of the symposium on manuscripts in southern Africa 21-23 November 1984. Cape Town: South African Library. 177-182.

Clements, D.W.G. 1986. Preservation and library school education programmes. Library association record. 88(3):136-137.

Cloonan, M.V. 1994. Global perspectives on preservation education. IFLA Publications 69. Munich: K.G. Saur.

Cloonan, M.V. 1997. Preservation without borders. Libri. 47:180-186.

Coates, P. 2001. JICPA survey of preservation resources in Africa 1999. Cape Town: JICPA.

Coleman, C.D.G. 1995. Preservation education directory. $7^{\text {th }}$ ed. Education Committee of the Preservation of Library Materials Section, ALCTS. [Online]. Available: http://www.ala.org/alcts/publications/presed.html [25 january 2002].

Conservation Online. 2005. Educational opportunities in museum, library, and archives conservation/preservation. [Online]. Available: http://palimpsest.stanford.edu/bytopic/education/ [29 December 2005].

Dalton, S. 1999. Microfilm and microfiche. NEDCC technical leaflet, section 5, leaflet I. [Online]. Available: http://www.nedcc.org/ plam3/tleaf5 I.htm [1 8 December 2005].

De Stefano, P. 2000. Preservation and conservation studies program: 1999 survey. (Unpublished).

Digital Imaging Project of South Africa. 2005. DISA: digital imaging project of South Africa. [Web site]. Available: http:// disa.nu.ac.zal [18 December 2005].

Dyab, M. 2002. Development of library and information science education in eastern and south Africa: an historical review. Harald of library science. 4 I (1-2):5-16.

Feather, J. 1986. Curriculum for the teaching of conservation. Library Association record. 88(10):499-501.

Feather, J. 2000. The role of library and archives schools. In Training for preservation management: the next step. Proceedings of the National Preservation Office annual seminar 1999. edited by. S. Thebridge. London: National Preservation Office. 19-23.

Harris, V. 1993. Going for green: public archive buildings in South Africa and the prospects for natural climate control. AMLIB newsletter. 53:12-18.

Kukubo, R.J. 1995. A review of areas of actual and potential co-operation in preservation and conservation efforts in eastern and southern Africa. In Proceeding of the pan-African conference on the preservation and conservation of library materials. Nairobi, Kenya 21-25 June 1993. IFLA Professional Reports 43. edited by J.M. Arnoult, V. Kremp and M. Musembi. The Hague, Netherlands: IFLA. 157-I6I.

Langlois, C. ed. 1999. Guide to higher education in Africa. London: Macmillan Reference.

Lor, P.L. 2005. Preserving African digital resources: is there a role for repository libraries? Library management. 26(1/2):63-72.

Lyall, ]. 1991. Developing education programs for library preservation in Australia. In Education and training for preservation and conservation: Papers of an international seminar on 'The teaching of preservation management for librarians, archivists and information scientists,' sponsored for IFLA, FID, and ICA, Vienna, April II-13, 1986. IFLA Publications 54. edited by J.R. Fang and A. Russell. Munich: K.G. Saur. 64-66.

Maree, J.C.N. 1981. Some thoughts on conservation. Jagger journal. 2:1-4.

Maree, J.C.N. 1988. Integrated pest management is not a new concept: a return to basics. Jagger journal. 9:12-19.

Matthews, G. and Thebridge, S. 2001. Preservation management training and education: developing a cross-sectoral approach. New library world. 102(1170/1171):443-451.

SA JnI Libs \& Info Sci 2006, 72(2) 
Mazikana, P.C. 1995. An evaluation of preservation and conservation programmes and facilities in Africa. In Proceeding of the pan-African conference on the preservation and conservation of library materials. Nairobi, Kenya 21-25 June 1993. IFLA Professional Reports 43. edited by J.M. Arnoult, V. Kremp and M. Musembi. The Hague, Netherlands: IFLA. 2 I-29.

Mboungou-Mayengué, D., ed. 1988. Directory of African Universities. 5th edition. Accra: Association of African Universities.

Meadows, A.J. 1987. Conservation and preservation: some questions answered. In Conservation in crisis. Proceeding of a seminar at Loughborough University of Technology 16-17 july 1987. National Preservation Office seminar papers 1. London: National Preservation Office. 19-22.

Mnjama, N.M. 1996. National archives and the challenges of managing the entire life cycle of records. S.A. archives journal 38:2432.

Mnjama. N. 2005. Archival landscape in Eastern and Southern Africa. Library management. 26(8/9):457-470.

Murray, K. 2002. Preservation Education and Training for South African Library and Archive Professionals and Students. Master's thesis, University of Cape Town.

National Library of Australia. 2002. Policy on preservation copying of collection materials. [Online]. Available: http://wrw.nla.gov. au/ policy/micro.htmi\#stan [18 December 2005].

National Library of South Africa. 2005. Preservation services. [Online]. Available: http://www.n/sa.ac.za/ services preservation. html [29 December 2005]

National Preservation Office. 2005. National Preservation Office. [Web site]. Available: http://www.bl.uk/services/npo/npo.html [29 December 2005].

Ngulube, P. 2003. Preservation and access to public records and archives in South Africa. Ph.D. diss., Pietermaritzburg: University of Natal. [Online]. Available: http://www.hs.unp.ac.za/infs/thesispn.pdf [18 December 2005].

Ogden, S. 1979. The impact of the Florence flood on library conservation in the United States of America: a study of the literature published 1956-1976. Restaurator. 3:1-36

Patkus, B.L. 1999. Monitoring temperature and relative humidity. NEDCC technical leaflet, section 2, leaflet I. [Online]. Available: http://www.nedcc. org/plam3/tleaf22.htm [18 December 2005].

Patkus, B.L. and Motylewski, K. 1999. Disaster planning. NEDCC technical leaflet, section 3, leaflet 3. [Online]. Available: http:// www.nedcc. org/plam3/tleaf33. htm [18 December 2005].

Pederson, A. ed. 1987. Keeping archives. Sydney: Australian Society of Archives Inc.

Peters, D. 1996a. Climates and microclimates: a new attitude to the storage of archival materials. AMLIB newsletter. 60:8-13.

Peters, D. 1996b. Our environment ruined? Environmental control reconsidered as a strategy for conservation. Journal of conservation and museum studies. [Online]. Available: http://palimpsest.stanford.edu/jcms/issuel/peters.html [IB December 2005].

Ratcliffe, F.W. 1985. The current situation in the United Kingdom. Journal of librarianship. 17(2):85-91.

Ratcliffe, F.W. 1986. Education in preservation for librarians and conservators. Library Association record. 88(10):493-497.

Ratcliffe, F.W. and Patterson, D. 1985. Preservation policies and conservation in British libraries: report of the Cambriclge University conservation project. Library and information research report 25. Wetherby, West Yorkshire: British Library.

Rhys-Lewis, J. 2000. National archives of Uganda: determination is all that it takes. International preservation news. 22-23:19-21.

Rosenberg, D. 1995. Everyday care of books in libraries. In Proceeding of the pan-African conference on the preservation and conservation of library materials. Nairobi, Kenya 21-25 June 1993. IFLA Professional Reports 43. edited by J.M. Arnoult, V. Kremp and M. Musembi. The Hague, Netherlands: IFLA. 77-87.

Russell, A. 1991. Qualifications of teachers for library preservation courses: cooperation between librarians and coriservators. In Education and training for preservation and conservation: Papers of an international seminar on 'The teaching of preservation management for librarians, archivists and information scientists,' sponsored for IFLA, FID, and ICA, Vienna, April I1-13, I986. IFLA Publications 54. edited by J.R. Fang and A. Russell. Munich: K.G. Saur. 82-85.

Society of American Archivists. 2005. Directory of archival education. [Online]. Available: http://www. archivists.org/prof-education/ edd-arched asp [29 December 2005].

Sonnet-Azize, R.G. 1995. Preservation and conservation measures in central Africa: proposals for training programmes. In Proceeding of the pan-African conference on the preservation and conservation of library materials. Nairobi, Kenya $21-25$ June 1993. IFLA Professional Reports 43. edited by J.M. Arnoult, V. Kremp and M. Musembi. The Hague, Netherlands: IFLA. I65168.

Southern African Development Community Secretariat Library. 1998. Directory of library and information schools in SADC region. Gaborone: Botswana.

Thebridge, S. and Matthews, G. 2000. Review of preservation management training in the UK and abroad: main findings from the Library and Information Commission. Research reports 48. London: National Preservation Office.

Twentyman Jones, L. 1987. Preservation officers and their training. In Books in peril: proceedings of the symposium on the preservation of library and archival materials in southern Africa held at the South African Library, Cape Town, 19-2/ November 1986. Cape Town: South African Library. 118-128.

University of Cape Town. 2002. The San (Bushman) photographs of Dorothea Bleek. Manuscripts and Archives Department. Web site]. Available: http://www. lib.uct.ac.za/mss/existing/DBleekXML/website/index.htm [18 December 2005].

University of Texas at Austin. 2005. School of Information academic programs. [Web site]. Available: http://www.ischool.utexas. edu/ programs/ [29 December 2005].

University of the Western Cape. 2001. Builders of the nation poster exhibit. Robben Island Mayibuye Archives. [Web site]. Available: http://www. mayibuye.org/posters/ [18 December 2005].

Wambugo, C.K. 1991. Special needs in education and training in the non-industrialised countries: Kenya. In Education and training for preservation and conservation: Papers of an international seminar on 'The teaching of preservation management for librarians, archivists and information scientists,' sponsored for IFLA, FID, and ICA, Vienna, April //-13, 1986. IFLA Publications 54. edited by J.R. Fang and A. Russell. Munich: K.G. Saur. 76-78. 
Weiner, M. 1986. AMLIB conservation workshop. AMLIB newsletter. 31 (August): 6-9.

Weiner, M. 1987. If not now, when? A management approach to environmental and pest control. In Books in peril: proceedings of the symposium on the preservation of library and archival materials in southern Africa held at the South African Library, Cape Town, 19-2I November 1986. Cape Town: South African Library. 62-70.

Westra, P.E. 1986. Preservation of library and archive material: developments in South Africa and abroad. In Bibliophilia Africana V: Proceedings of the fifth South African conference of bibliophiles. South African Library, Cape Town 19-22 November 1985. Cape Town: South African Library. 137-146.

Westra, P.E. 1987. Preservation in southern Africa: the current situation. In Books in Peril: Proceedings of the Symposium on the Preservation of Library and Archives Materials in Southern Africa. South African Library, Cape Town. 19-21 November 1986. Cape Town: South African Library. 26-38.

Wiseman, C. and Arnott, J. 2002. Preservation education directory. $8^{\text {th }}$ ed. Education Committee of the Preservation of Library Materials Section, ALCTS. [Online]. Available: http://www.ala.org/ala/alctscontent/alctspubsbucket/webpublications/ alctspreservation/preseddir/home.htm [29 December 2005]

Youth-In-Finance Counselling Services. 1999. Directory of educational programmes. Durban: Butterworths. 